Vol. 1 No. 3 Desember 2021, e-ISSN : 2797-8842 | p-ISSN : 2797-9431

\title{
PENGGUNAAN METODE PICTURE TO PICTURE PADA MASA PANDEMI COVID 19 DENGAN APLIKASI GOOGLE CLASSROOM DALAM MENINGKATKAN HASIL BELAJAR GEOGRAFI SISWA KELAS XI SOS 3 SMA N 106 JAKARTA
}

\author{
MEDINA GUSTININGRUM \\ SMA N 106 Jakarta \\ e-mail: medinaningrumbasuki@gmail.com
}

\begin{abstract}
ABSTRAK
Proses pembelajaran yang kurang efektif, guru mengajar tidak menggunakan metode yang bisa meningkatkan rasa ingin tahu siswa dalam menggali ilmu, sehingga terkesan guru tersebut menoton. Hal demikian dapat mempengaruhi hasil belajar siswa tidak mencapai hasil yang diinginkan, khususnya dalam pembelajaran Geografi materi Persebaran Flora dan Fauna. Penelitian ini bertujuan untuk mengetahui dan memperoleh informasi dari lapangan tentang hal-hal yang berhubungan dengan peningkatan hasil belajar siswa terhadap Geografi materi Persebaran Flora dan Fauna melalui penggunaan model Picture To Picture pada siswa kelas XI-SOS 3 SMA Negeri 106 Jakarta Timur. Penelitian Tindakan Kelas (PTK) yang dilakukan oleh peneliti dan guru kolaborator melalui 2 siklus. Dimana setiap siklus dilaksanakan 2 kali pertemuan. Setiap siklus terdiri dari empat kegiatan yaitu perencanaan, pelaksanaan tindakan, observasi dan evalusi, serta refleksi. Hasil belajar Geografi siwa dapat ditingkatkan dengan penerapan metode Picture To Picture. Hal ini dapat dilihat dari nilai hasil soal individu pada siklus I dan II . Dari hasil sebelum siklus I mengalami peningkatan, juga pada siklus II mengalami peningkatan. Setelah ada tindakan dan refleksi pada pelaksanaan siklus I dan II dengan menggunakan metode picture to picture maka ada perubahan yang sangat berarti ke arah yang sangat baik.
\end{abstract}

Kata kunci : hasil belajar, pembelajaran kooperatif, Picture To Picture, PTK (Penelitian Tindakan Kelas).

\section{ABSTRACT}

The learning process is less effective, the teaching teacher does not use methods that can increase students' curiosity in exploring knowledge, so that the teacher seems to be watching. This can affect student learning outcomes that do not achieve the desired results, especially in learning Geography of the material for the distribution of flora and fauna. This study aims to find out and obtain information from the field on matters relating to improving student learning outcomes on the material Geography of the Distribution of Flora and Fauna through the use of the Picture To Picture model in class XI-SOS 3 students of SMA Negeri 106 East Jakarta. Classroom Action Research (CAR) conducted by collaborating researchers and teachers through 2 cycles. Where each cycle is carried out 2 meetings. Each cycle consists of four activities, namely planning, implementing actions, observing and evaluating, and reflecting. Geography learning outcomes of students can be improved by applying the Picture To Picture method. This can be seen from the value of the results of individual questions in cycles I and II. From the results before the first cycle experienced an increase, also in the second cycle there was an increase. After there was action and reflection on the implementation of cycles I and II using the picture to picture method, there was a very significant change in a very good direction. Keywords: learning outcomes, cooperative learning, Picture To Picture, CAR (Classroom Action Research).

\section{PENDAHULUAN}

Pendidikan harus senantiasa dinamis seiring dengan kemajuan teknologi dan mampu mengimbangi perubahan-perubahan yang terjadi sebagai tantangan global. Untuk memenuhi tantangan global maka perlu diadakan perbaikan pendidikan. Perkembangan teknologi tak luput 
dari perkembangan proses belajar mengajar. Adanya teknologi belajar online atau daring memungkinkan tenaga pengajar dan siswa berinteraksi jarak jauh.

Proses belajar-mengajar yang baik adalah proses terciptanya interaksi guru dan peserta didik. Proses interaksi dapat terjadi apabila guru mampu mendukung siswa agar terdorong oleh keinginannya sendiri guna menerapkan dan mengamalkan materi yang disampaikan oleh guru. Pada saat pandemi covid 19, pemerintah memutuskan untuk seluruh aktivitas berada di rumah, tak terkecuali dunia pendidikan. Belajar jarak jauh memerlukan banyak kesiapan, antara lain teknologi, karakteristik pengajar dan karakteristik siswa.

Pembelajaran geografi pada jenjang pendidikan menengah atas sangat penting untuk diajarkan, hal ini dikarenakan siswa yang belajar di sekolah berasal dari lingkungan yang berbeda-beda. Melalui pengajaran geografi, siswa mampu memahami permasalahan yang ada di lingkungannya. Selain itu, dengan pengajaran geografi siswa dapat memperoleh pengetahuan, keterampilan, sikap, dan kepekaan untuk menghadapi hidup dengan segala tantangan yang ada. Dalam rangka mencapai keberhasilan dalam pembelajaran Geografi hendaknya seorang guru mampu memberikan inovasi dalam menyampaikan pengajaran salah satunya pada mata pelajaran Geografi. Inovasi dalam pembelajaran dapat dilakukan melalui pemilihan metode atau model pembelajaran yang menyenangkan, menarik, memotivasi, melibatkan siswa dalam pembelajaran, serta dapat juga dengan bantuan media atau alat peraga yang sesuai dengan materi.

Menganalisis sebaran flora dan fauna di Indonesia dan dunia berdasarkan karakteristik ekosistem merupakan materi yang terdapat pada kelas XI semester ganjil dan materi ini adalah materi yang mendeskripsikan serta mengidentifikasi flora dan fauna di Indonesia dan dunia berdasarkan karakteristik ekosistem.Pada saat pembelajaran Jarak jauh (PJJ) Materi sebaran flora dan fauna merupakan materi yang sulit untuk dipahami karena bersifat sangat kompleks, sehingga harus disalurkan melalui model pembelajaran yang menarik dan inovatif agar siswa tidak merasa bosan.

Berdasarkan hasil observasi yang dilakukan di SMA Negeri 106 Jakarta, terdapat beberapa permasalahan yang muncul dalam pembelajaran geografi antara lan: (1) kurangnya perhatian peserta didik pada penjelasanpenjelasan guru; (2) perhatian peserta didik pada materi pelajaran hanya terjadi pada awal pembelajaran saja; (3) Masih ada beberapa siswa yang sulit menerima pelajaran ketika proses pembelajaran sedang berlangsung; (4) Penggunaan model dalam pembelajaran geografi kurang bervariasi, sehingga hal ini menyebabkan motivasi dan hasil belajar siswa rendah.

Mengacu pada fakta yang ada, dapat diketahui bahwa pembelajaran geografi belum berhasil. Selain itu, pelaksanaan proses pembelajaran pada masa pandemi (PJJ) masih berpusat pada guru, sehingga menyebabkan siswa cenderung pasif. Model pembelajaran yang digunakan kurang bervariasi dan menyenangkan bagi siswa, sehingga menyebabkan motivasi dan aktivitas siswa masih rendah. Model pembelajaran picture to picture jarang dilaksanakan oleh guru terutama pada mata pelajaran geografi. Berdasarkan permasalahan tersebut, diadakanlah penelitian yang berhubungan dengan metode pembelajaran picture to picture.

Dalam pembelajaran, perubahan perilaku yang harus dicapai oleh peserta didik setelah melaksanakan aktivitas belajar dirumuskan dalam tujuan pembelajaran. Peristiwa belajar yang terjadi dalam diri peserta didik dapat diamati dari perbedaan perilaku (kinerja) sebelum dan sesudah berada ketika dalam belajar. Hasil Belajar merupakan perubahan perilaku yang diperoleh peserta didik setelah mengalami kegiatan belajar (Rifa'i, 2010).

Menurut Agus Suprijono (2009:110) Model pembelajaran Picture and Picture adalah metode belajar yang menggunakan gambar dipasangkan atau diurutkan menjadi urutan logis. Model Pembelajaran ini mengandalkan gambar sebagai media dalam proses pembelajaran. Gambar-gambar ini menjadi faktor utama dalam proses pembelajaran. Diharapkan siswa mampu untuk mengurutkan gambar-gambar secara logis dan memberikan alasan/dasar pemikiran urutan gambar tersebut 
Pembelajaran ini memiliki ciri Aktif, Inovatif, Kreatif, dan Menyenangkan. Model Pembelajaran apapun yang digunakan selalu menekankan aktifnya peserta didik dalam setiap proses pembelajaran. Inovatif setiap pembelajaran harus memberikan sesuatu yang baru, berbeda dan selalu menarik minat peserta didik. Dan Kreatif, setiap pembelajarnya harus menimbulkan minat kepada peserta didik untuk menghasilkan sesuatu atau dapat menyelesaikan suatu masalah dengan menggunakan metoda, teknik atau cara yang dikuasai oleh siswa itu sendiri yang diperoleh dari proses pembelajaran.

Model Pembelajaran ini mengandalkan gambar sebagai media dalam proses pembelajaran. Gambar-gambar ini menjadi factor utama dalam proses pembelajaran. Sehingga sebelum proses pembelajaran guru sudah menyiapkan gambar yang akan ditampilkan baik dalam bentuk kartu atau dalam bentuk carta dalam ukuran besar. Atau jika di sekolah sudah menggunakan ICT dalam menggunakan Power Point atau software yang lain.

Metode Picture to picture dianggap layak mewakili pada materi Persebaran flora dan fauna pada aplikasi google classroom. Guru memberi contoh yang dikirim melalui file ke materi pada menu stream atau tugas, dan siswa mengembangkan contoh gambar tersebut dengan mencari dari sumber lain, kemudian hasil pekerjaan siswa dikirim ke google classroom.

Model pembelajaran merupakan salah satu faktor yang mempengaruhi keberhasilan guru dalam melaksanakan kegiatan pembelajaran. Model pembelajaran yang diterapkan guru dapat menentukan tingkat keefektivan siswa dan hasil belajar siswa. Semakin tepat memilih model pembelajaran yang akan diterapkan guru diharapkan semakin efektif dalam mencapai tujuan pembelajaran. Berdasarkan keunggulan metode pembelajaran Picture to picture mampu meningkatkan partisipasi aktif siswa dalam kegiatan pembelajaran serta meningkatkan hasil belajar siswa, maka penerapannnya akan lebih efektif.

\section{METODE PENELITIAN}

Penelitian ini dilakukan dengan menggunakan metode PenelitianTindakan Kelas yang terdiri dari 2 Siklus. PTK ini mengacu pada desain penelitian menurut Kemmis (adaptasi dari Mc Niff,1988:27) seperti berikut ini: Menurut desain tersebut, setiap siklus terdiri dari empat tahap yaitu perencanaan, pelaksanaan, pengamatan, dan refleksi. Dalam penelitian ini, setiap siklus terdiri dari tiga kali $(3 \mathrm{X})$ pertemuan dan setiap pertemuan terdiri dari pendahuluan, kegiatan inti, dan penutup.

Sumber data penelitian yang berasal dari siswa sebagai subjek penelitian berupa data kuantitatif adalah nilai tes. Sedangkan data kualitatif berupa hasil angket/kuesioner dan atau wawancara. Sumber data kuantitatif lain berasal dari dokumen peneliti sendiri, dokumen sekolah, atau dokumen teman sejawat. Data kulitatif berupa hasil observasi yang diisi oleh observer pada saat mengamati proses pembelajaran.

Untuk mendapat data hasil belajar dalam penelitian ini digunakan. Butir Soal Tes sebagaimana yang terlampir. Sedangkan untuk mendapat data kualitatif tentang kegiatan guru dalam proses pelaksanaan pembelajaran digunakan instrumen berupa lembar observasi kegiatan guru sebagai berikut: (format lembar observasi dan cara mengolah/kriteria hasilnya). Untuk mendapat data kualitatif tentang kegiatan siswa dalam proses pelaksanaan pembelajaran digunakan instrumen berupa lembar observasi kegiatan siswa sebagai berikut: (formatnya lembar observasi dan cara mengolah / kriteria hasilnya). Upaya peneliti untuk mendapatkan data tentang Menganalisis Persebaran Flora dan Fauna digunakan angket/kuesioner.

Hasil Belajar dianalisis dengan analisis deskriptif komparatif yaitu menghitung rerata nilai tes tiap pertemuan/siklus, dan membandingkan, serta menghitung perubahan /kenaikannya dengan nilai tes antar siklus maupun dengan indikator kinerja. Observasi maupun Wawancara dianalisis secara deskriptif kualitatif berdasarkan hasil observasi dan refleksi.

Data kuantitatif yang diperoleh berupa nilai hasil tes siswa setiap pertemuan dihitung reratanya, dianalisis jumlah siswa yang sudah tuntas dan yang belum tuntas, nilai tertinggi maupun nilai terendah. Hasil-hasil analisis tersebut direkapitulasi dan dihitung besar perubahan dan peningkatan yang terjadi dari pertemuan ke pertemuan berikutnya dalam satu siklus. Data 
yang didapat dari siklus kedua dianalisis dengan cara yang sama, kemudian dari hasil analisis akhir dari setiap siklus dihitung perubahan/peningkatannya dan disertai dengan deskripsi kritis tentang penyebab perubahan tersebut.

Data kualitatif berupa hasil observasi yang telah diisi oleh observer dalam setiap pertemuan kemudian dianalisis secara deskriptif sesuai dengan kriteria yang telah ditentukan pada instrumen. Hasil pengamatan tersebut juga dijadikan bahan diskusi dan perbaikan pada tahap refleksi.

Penelitian tindakan kelas ini yang merupakan upaya peneliti untuk meningkatkan hasil belajar Geografi terutama pada materi KD 3.1 Menganalisis Persebaran Flora dan Fauna dengan menggunakan metode Picture to picture. Penelitian tindakan kelas ini dinyatakan berhasil bila hasil analisis data akhir sama atau lebih besar dari kriteria ketuntasan minimal dari KD 3.1 Menganalisis Persebaran Flora dan fauna sebesar 75.

\section{HASIL DAN PEMBAHASAN}

Pada awal Kegiatan Belajar Mengajar(KBM), Pembelajaran Jarak Jauh (PJJ) dengan materi persebaran flora dan fauna belum menggunakan metode picture to picture, tetapi masih menggunanakan metode ceramah, tanya jawab dan penugasan seperti biasa pada sistem pembelajaran daring (online) dengan menggunakan aplikasi Google Classroom. Fokus perhatian dalam penelitian ini adalah penerapan pembelajaran metode picture to picture agar menarik perhatian, dan motivasi serta kesungguhan siswa lebih berusaha meningkatkan hasil belajarnya.

Setelah pembahasan materi persebaran flora dan fauna selesai, dilaksanakan tes atau ulangan harian untuk menguji keberhasilan pemahaman siswa terhadap materi persebaran flora dan fauna. Dengan menggunakan aplikasi Google Classroom , soal yang ada pada google form di upload ke aplikasi Google Classroom kelas XI sos 3 yang dikerjakan selama 60 menit dengan jumlah soal 20. Hasil yang dicapai siswa seperti tabel 4.1 dan lampiran hasil tes UH 1 XI sos 3.

Tabel 1. Rerata nilai Kelas Persebaran flora dan fauna 7 September 2021

\begin{tabular}{|c|c|c|c|c|}
\hline No & Kelas & Rata-rata & Median & Rentang \\
\hline 1. & XI sos 1 & 75,68 & $80-100$ & $40-95$ \\
\hline 2. & XI sos 2 & 74,1 & $75-100$ & $40-95$ \\
\hline 3. & XI sos 3 & 64,31 & $70-100$ & $5-85$ \\
\hline 4. & XI sos 4 & 72,69 & $75-100$ & $40-100$ \\
\hline
\end{tabular}

Berdasarkan tabel tersebut, ternyata rata-rata nilai kelas XI sos 3 yang terrendah dibandingkan dengan kelas yang lain, dengan rata-rata nilai 64,31. Hal ini dapat diartikan bahwa siswa kelas XI sos 3 belum tuntas untuk materi persebaran flora dan fauna atau masih dibawah KKM 75, sehingga perlu dianalisis, diulang kembali.Berdasarkan hasil tes UH 1 kelas XI sos 3,diadakan kegiatan pengamatan/menganalisis terhadap hasil tes kelas XI sos 3. Hasil analisis terdapat pada lampiran 4.2 analisa siswa dan soal

Dengan melihat analisis siswa dan soal, perlu diadakan suatu tindakan berupa pengulangan materi persebaran flora dan fauna tetapi dengan menggunakan metode yang baru, yaitu picture dan picture pada aplikasi google classroom.

\section{Hasil}

\section{Pelaksanaan Siklus 1}

\section{a. Tahap Perencanaan}

Supaya pembelajaran geografi berjalan dengan baik dan sesuai dengan tujuan pembelajaran yang telah ditetapkan pada kegiatan belajar mengajar maka terlebih dahulu mempersiapkan perangkat pembelajaran yang sesuai dengan pembelajaran Pendidikan geografi 
dengan menerapkan metode pembelajaran picture to picture pada aplikasi google classroom yaitu RPP, LKS, dan contoh gambar persebaran flora dan fauna, serta Soal formatif.

\section{b. Tahap Pelaksanaan}

Pelaksanaan ataupun penerapan yang telah dirancang pada RPP terdiri dari pendahuluan, kegiatan inti dan penutup dengan menggunakan metode picture and picture melalui aplikasi Google Classroom daring (online) dengan google meet (lampiran foto).

Pada pertemuan ke 2 dilakukan kegiatan observasi atau mengamati hasil pekerjaan siswa berupa tugas membuat peta persebaran flora dan fauna dengan hasil seperti pada lampiran foto Contoh hasil tugas siswa (pembuatan peta persebaran flora dan fauna)

Di akhir pembelajaran setelah masing-masing siswa menyelesaikan tugas dan tanggung jawab masing-masing siswa sesuai dengan waktu yang telah disediakan, kemudian secara individu siswa dilanjutkan dengan evaluasi / tes formatif selama 60 menit. Guru mengingatkan siswa untuk melaksanakan evaluasi secara individu melalui aplikasi google classroom.

Untuk menguji keberhasilan tindakan pada siklus I ini diadakan tes atau penilaian terhadap materi persebaran flora dan fauna. Dari hasil tes penilaian pada siklus I, diperoleh hasil sebagai berikut :

Tabel 2. Perolehan hasil tes formatif siklus 1

\begin{tabular}{|c|c|c|c|c|c|c|}
\hline & & Nilai Awa & & Nilai Siklu & Is 1 & \\
\hline & Nilai & i $\quad$ Frekuens & e (\%) ${ }^{\text {Prosentas }}$ & $\begin{array}{ll} & \text { Frekuens } \\
\text { i } & \end{array}$ & e $(\%)$ & Prosentas \\
\hline & $<50$ & 6 & 16.67 & 3 & & 44.44 \\
\hline 59 & $50-$ & 7 & 19.44 & 1 & & 2.78 \\
\hline 69 & $60-$ & 4 & 11.11 & 2 & & 0.06 \\
\hline 79 & $70-$ & 12 & 33.33 & 11 & & 0.31 \\
\hline 89 & $80-$ & 7 & 19.44 & 7 & & 0.06 \\
\hline 100 & $90-$ & - & - & 13 & & 0.11 \\
\hline $\mathrm{h}$ & Jumla & 36 & 100 & 37 & & 100 \\
\hline
\end{tabular}

Keterangan :

\begin{tabular}{|l|l|l|}
\hline Nilai & Awal & Siklus 1 \\
\hline Tertinggi & 85 & 95 \\
\hline Terendah & 0,5 & 45 \\
\hline Rata-Rata & 64,31 & 79,46 \\
\hline
\end{tabular}

\section{c. Tahap Analisis}

Jumlah siswa yang mencapai Kriteria Ketuntasan Minimal setelah pengunaan metode picture to picture dengan aplikasi google classroom sebanyak 28 siswa (76\%) dan 9 siswa (24\%) mendapatkan nilai dibawah kriteria ketuntasan minimal, dibandingkan dengan sebelum penggunaan metode picture to picture google classroom yang hanya 12 siswa (33\%) dan 24 siswa $(67 \%)$ mendapat nilai dibawah kriteria ketuntasan minimal.

Presentase ketuntasan siswa mengalami peningkatan (sebelumnya sebesar 67\%, siklus I sebesar 76\%), dengan peningkatan nilai rata-rata sebesar 15,2 (nilai rata-rata sebelumnya sebesar 64,3 dan nilai rata-rata siklus I sebesar 79,5). Artinya bahwa tingkat keberhasilan dari penggunaan metode picture to picture dengan aplikasi google classroom telah memberikan pengaruh yang besar terhadap peningkatan hasil belajar.

Dari perbandingan statistik data nilai awal dengan data perolehan nilai tes formatif siklus 1 nilai terendahnya mengalami kenaikan dan nilai tertingginya mengalami kenaikan nilai 
serta nilai rata-ratanya mengalami kenaikan, dan nampak terlihat dari rentang nilai yang didapat nilai awal yaitu dari 3 sampai dengan 8 dan rentang nilai siklus 1 yaitu dari 3 sampai dengan 9 serta sama sama mendapat nilai kurang dari 50 cukup banyak sehingga dapat disimpulkan kurang signifikan, dan mungkin pembelajaran dengan model picture to picture masih baru bagi siswa atau belum sepenuhnya dipahami oleh semua siswa, hal tersebut sebagaimana pada hasil obserasi siswa berikut ini.

Tabel 3. Hasil Obserasi Siswa Siklus 1

\begin{tabular}{|c|c|c|c|c|}
\hline \multirow{3}{*}{ NO } & \multirow{3}{*}{ PENGAMATAN } & \multicolumn{3}{|r|}{ SIKLUS I } \\
\hline & & \multicolumn{2}{|c|}{ PENINGKATAN } & \multirow{2}{*}{ CACATAN LAPANGAN } \\
\hline & & Ya & Tidak & \\
\hline 1 & $\begin{array}{l}\text { Kesiapan siswa mengikuti } \\
\text { pelajaran }\end{array}$ & & Tidak & $\begin{array}{l}\text { Sangat banyak siswa yang masih } \\
\text { terlambat masuk kelas g.meet }\end{array}$ \\
\hline 2 & $\begin{array}{l}\text { Semangat siswa terhadap } \\
\text { materi yang disa jikan }\end{array}$ & Ya & & $\begin{array}{l}\text { Muncul dari siswa yang } \\
\text { tergolong lumayan berprestasi }\end{array}$ \\
\hline 3 & $\begin{array}{l}\text { Perhatian siswa terhadap materi } \\
\text { pelajaran dengan menggunakan } \\
\text { Picture to picture }\end{array}$ & & Tidak & $\begin{array}{l}\text { Sedikit sekali siswa yang } \\
\text { menikmati model Picture to } \\
\text { picture }\end{array}$ \\
\hline 4 & $\begin{array}{l}\text { Kecenderungan hati siswa } \\
\text { dalam menerima pelajaran }\end{array}$ & Ya & & $\begin{array}{l}\text { Masih terbiasa dengan model } \\
\text { ceramah dari guru }\end{array}$ \\
\hline 5 & $\begin{array}{l}\text { Rasa senang siswa dalam } \\
\text { mengajukan pertanyaan }\end{array}$ & Ya & & $\begin{array}{l}\text { Dari } 40 \text { siswa yang bertanya } \\
\text { hanya } 5 \text { orang siswa }\end{array}$ \\
\hline 6 & $\begin{array}{l}\text { Rasa senang siswa dalam } \\
\text { menjawab pertanyaan }\end{array}$ & Ya & & $\begin{array}{l}\text { Datang dari siswa yang } \\
\text { tergolong lumayan dan pintar }\end{array}$ \\
\hline 7 & $\begin{array}{l}\text { Sikon siswa antosias dalam } \\
\text { pembelajaran Picture to picture }\end{array}$ & Ya & & $\begin{array}{l}\text { Terkesan dalam mengikuti } \\
\text { pembelajaran seperti permainan }\end{array}$ \\
\hline 8 & $\begin{array}{l}\text { Kecenderungan dan keseriusan } \\
\text { siswa dalam menerima } \\
\text { pelajaran }\end{array}$ & & Tidak & $\begin{array}{l}\text { Ada pada siswa yang tergolong } \\
\text { pintar }\end{array}$ \\
\hline 9 & $\begin{array}{l}\text { Perhatian siswa dalam } \\
\text { melaksanakan tugas }\end{array}$ & & Tidak & $\begin{array}{l}\text { Kurang bersemangat dan masih } \\
\text { tertumpu pada sedikit siswa }\end{array}$ \\
\hline 10 & $\begin{array}{lrr}\begin{array}{l}\text { Keinginan } \\
\text { mengerjakan }\end{array} & \text { siswa } & \text { dalam } \\
\text { diberikan guru } & & \text { yang } \\
\end{array}$ & & Tidak & $\begin{array}{l}\text { sedikit dan bahkan kurang } \\
\text { antusias }\end{array}$ \\
\hline 11 & $\begin{array}{l}\text { Keinginan siswa dalam } \\
\text { mencatat materi yang diajarkan } \\
\text { guru }\end{array}$ & Ya & & $\begin{array}{l}\text { Semua mencatat seperti yg } \\
\text { terdapat di google classroom }\end{array}$ \\
\hline 12 & $\begin{array}{l}\text { Kesiapan dan kesungguhan } \\
\text { siswa mengikuti dan } \\
\text { menyelesaikan ulangan harian }\end{array}$ & & Tidak & $\begin{array}{l}\text { Nampak seperti siswa kurang } \\
\text { antusias }\end{array}$ \\
\hline
\end{tabular}

\section{d. Tahap Refleksi}

Dari hasil pengamatan setelah kegiatan pembelajaran selesai dapat disimpulkan sebagai berikut :

1. Pemberian LKS dapat membantu guru dalam menyampaikan materi dan suasana kelas lebih kondusif dan waktu untuk mencatat lebih cepat.

2. Mengingatkan pada siswa bahwa sebelum membahas materi baru siswa perlu mempelajari terlebih dahulu di rumah.

3. Guru memberikan motivasi kepada siswa apabila terjadi peningkatan nilai dari tes sebelumnya.

4. Meningkatkan partisipasi siswa secara maksimal di dalam tugas dan tanggung jawabnya. 
5. Soal / tugas yang diberikan, soal tes formatif tidak terlalu banyak karena sesuai dengan waktu.

Berdasarkan uraian di atas dan siswa yang mendapat nilai kurang dari 50 cukup banyak sehingga dapat disimpulkan kurang signifikan, dan mungkin pembelajaran dengan model picture to picture masih baru bagi siswa atau belum sepenuhnya dipahami oleh semua siswa dengan demikian guru menyatakan perlu untuk melaksanakan pembelajaran metode picture and picture siklus 2 dengan melakukan perbaikan-perbaikan seperti diuraikan di atas.

\section{Pelaksanaan Siklus 2}

a. Tahap Pelaksanaan

Untuk menguji keberhasilan tindakan pada siklus II ini diadakan tes atau penilaian terhadap materi persebaran flora dan fauna. Dari hasil tes penilaian pada siklus II, diperoleh hasil sebagai berikut :

Tabel 5. Perolehan nilai tes formatif siklus 2

\begin{tabular}{|c|c|c|c|c|}
\hline \multirow[b]{2}{*}{ Nilai } & \multicolumn{2}{|c|}{ Data Nilai Siklus 1} & \multicolumn{2}{|c|}{ Data Nilai Siklus 2} \\
\hline & $\begin{array}{ll} & \text { Frekue } \\
\text { nsi } & \end{array}$ & $\%) \quad$ Prosentase( & $\begin{array}{ll} & \text { Frekue } \\
\text { nsi } & \end{array}$ & $\%) \quad$ Prosentase \\
\hline$<50$ & 3 & 8.11 & - & - \\
\hline $\begin{array}{|ll|}59 & 50-\end{array}$ & 1 & 2.70 & 2 & 5.41 \\
\hline $69 \quad 60-$ & 2 & 5.41 & 1 & 2.70 \\
\hline $79 \quad 70-$ & 11 & 29.73 & 12 & 32.43 \\
\hline $89 \quad 80-$ & 7 & 18.92 & 8 & 21.62 \\
\hline $100 \quad 90-$ & 13 & 35.14 & 14 & 37.84 \\
\hline $\begin{array}{ll} & \text { Juml } \\
\text { ah } & \\
\end{array}$ & 37 & 100 & 37 & 100 \\
\hline
\end{tabular}

Keterangan :

\begin{tabular}{|l|l|l|}
\hline & Data Nilai Siklus 1 & Data Nilai Siklus 2 \\
\hline Nilai tertinggi & 95 & 95 \\
\hline Nilai terendah & 45 & 55 \\
\hline Rata-Rata & 79,46 & 86,35 \\
\hline
\end{tabular}

\section{b. Tahap Analisis}

Presentase ketuntasan siswa mengalami peningkatan (siklus I sebesar $76 \%$, siklus II sebesar 86\%), dengan peningkatan nilai rata-rata sebesar 9,2 (nilai rata-rata siklus I sebesar 79,46 dan nilai rata-rata siklus II sebesar 86,35). Artinya bahwa tingkat keberhasilan dari penggunaan metode picture to picture dengan aplikasi google classroom telah memberikan pengaruh yang besar terhadap peningkatan hasil belajar.

Hasil analisis wawancara secara umum terhadap siswa di kelas google meet, setelah jam pelajaran berakhir, sebagian besar siswa menyatakan bahwa dengan pembelajaran metode picture and picture lebih enak dan lebih dapat memahami materi dibanding dengan pembelajaran sebelumnya. 


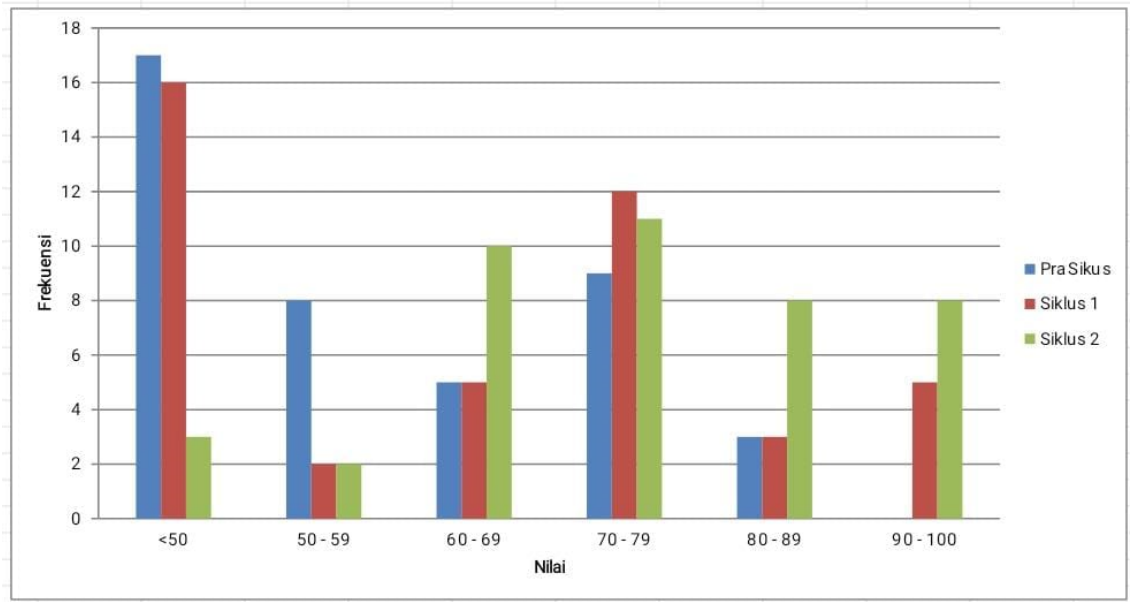

Gambar 1. Grafik Perolehan nilai tes formatif

Dari hasil perbandingan perolehan nilai tes formatif pada siklus 1 dengan siklus 2 secara umum mengalami kenaikan yaitu dimana rata-ratanya dari 79,46 . naik menjadi 86,35 dan nilai tertinggi tetap 95 serta nilai terendah dari 45 menjadi 55. Jadi dari angka statistik di atas dapat disimpulkan bahwa dengan pembelajaran metode picture and picture dapat meningkatkan motivasi dan partisipasi siswa dalam belajar. hal tersebut sebagaimana pada hasil obserasi siswa berikut ini

Tabel 6. Hasil Obserasi Siswa Siklus 2

\begin{tabular}{|c|c|c|c|c|}
\hline \multirow{3}{*}{ NO } & \multirow{3}{*}{ PENGAMATAN } & \multicolumn{3}{|r|}{ SIKLUS II } \\
\hline & & \multicolumn{2}{|c|}{ PENINGKATAN } & \multirow{2}{*}{ CACATAN LAPANGAN } \\
\hline & & $\mathbf{Y a}$ & Tidak & \\
\hline 1 & $\begin{array}{l}\text { Kesiapan siswa mengikuti } \\
\text { pelajaran }\end{array}$ & $\mathbf{Y a}$ & & $\begin{array}{l}\text { Sudah tampak dengan adanya } \\
\text { buku dan kehadiran siswa yang } \\
\text { tidak terlambat masuk g,meet }\end{array}$ \\
\hline 2 & $\begin{array}{l}\text { Semangat siswa terhadap } \\
\text { materi yang disa jikan }\end{array}$ & $\mathbf{Y a}$ & & Katagori sepenuhnya semangat \\
\hline 3 & $\begin{array}{l}\text { Perhatian siswa terhadap } \\
\text { materi pelajaran dengan } \\
\text { menggunakan picture and } \\
\text { picture }\end{array}$ & $\mathbf{Y a}$ & & $\begin{array}{l}\text { Sebagian besar siswa sudah } \\
\text { memahami cara belajar dengan } \\
\text { metode Picture and picture }\end{array}$ \\
\hline 4 & $\begin{array}{l}\text { Kecenderungan hati siswa } \\
\text { dalam menerima pelajaran }\end{array}$ & Ya & & $\begin{array}{l}\text { Sebagian besar siswa sudah } \\
\text { menikmati dan ceria }\end{array}$ \\
\hline 5 & $\begin{array}{l}\text { Rasa senang siswa dalam } \\
\text { mengajukan pertanyaan }\end{array}$ & $\mathbf{Y a}$ & & $\begin{array}{l}\text { Dari } 40 \text { siswa yang bertanya ada } \\
15 \text { orang siswa }\end{array}$ \\
\hline 6 & $\begin{array}{l}\text { Rasa senang siswa dalam } \\
\text { menjawab pertanyaan }\end{array}$ & $\mathbf{Y a}$ & & $\begin{array}{l}\text { Sudah agak merata antara siswa } \\
\text { yang pintar sedang dan kurang } \\
\text { terwakili dalam menjawab } \\
\text { pertanyaan }\end{array}$ \\
\hline 7 & $\begin{array}{l}\text { Sikon siswa antosias dalam } \\
\text { pembelajaran picture and } \\
\text { picture }\end{array}$ & Ya & & $\begin{array}{l}\text { Sebagian besar menikmati } \\
\text { pembelajaran metode Spicture } \\
\text { and picture }\end{array}$ \\
\hline 8 & $\begin{array}{l}\text { Kecenderungan dan keseriusan } \\
\text { siswa dalam menerima } \\
\text { pelajaran }\end{array}$ & $\mathbf{Y a}$ & & $\begin{array}{ll}\text { Sudah merata pada semua } \\
\text { siswa }\end{array}$ \\
\hline 9 & $\begin{array}{l}\text { Perhatian siswa dalam } \\
\text { melaksanakan tugas }\end{array}$ & $\mathbf{Y a}$ & & $\begin{array}{l}\text { Bersemangat dan sedikit } \\
\text { tertumpu pada siswa pintar dan } \\
\text { sedang }\end{array}$ \\
\hline
\end{tabular}


Vol. 1 No. 3 Desember 2021, e-ISSN : 2797-8842 | p-ISSN : 2797-9431

\begin{tabular}{|c|c|c|c|}
\hline 10 & $\begin{array}{lrr}\text { Keinginan } & \text { siswa } & \text { dalam } \\
\text { mengerjakan } & \text { tugas } & \text { yang } \\
\text { diberikan guru } & & \\
\end{array}$ & Ya & $\begin{array}{l}\text { Sebagian besar ingin cepat } \\
\text { menyelesaikan dan mencari tahu }\end{array}$ \\
\hline 11 & $\begin{array}{l}\text { Keinginan siswa dalam } \\
\text { mencatat materi yang diajarkan } \\
\text { guru }\end{array}$ & $\mathbf{Y a}$ & $\begin{array}{l}\text { Semua mencatat seperti yang } \\
\text { terdapat dalam google classroom }\end{array}$ \\
\hline 12 & $\begin{array}{l}\text { Kesiapan dan kesungguhan } \\
\text { siswa mengikuti dan } \\
\text { menyelesaikan ulangan harian }\end{array}$ & $\mathbf{Y a}$ & $\begin{array}{l}\text { Nampak seperti siswa sudah } \\
\text { punya semangat }\end{array}$ \\
\hline
\end{tabular}

\section{c. Tahap Refleksi}

Dari hasil pengamatan setelah kegiatan pembelajaran selesai dapat disimpulkan sebagai berikut :

1. Ternyata setelah mengingatkan siswa untuk banyak berlatih dan mengamati gambar sebelum membahas materi baru terlihat manfaatnya yaitu siswa dapat memberi tanggapan dan dapat menyelesaikan tugas masing-masing karena sudah memiliki bekal sebelumnya.

2. Perlu dengan terus menerus memberikan motivasi kepada siswa apabila terjadi peningkatan nilai dari tes sebelumnya.

3. Perlu meningkatkan partisipasi semua siswa secara maksimal di dalam tugas dan tanggung jawab..

Dengan demikian guru menganggap cukup pelaksanaan pembelajaran metode picture and picture siklus 2 dengan melakukan perbaikan-perbaikan seperti diuraikan di atas pada pembelajaran yang lain terutama penekanan pada peningkatan motivasi berprestasi dalam belajarnya.

\section{Pembahasan}

.Dari hasil data diketahui bahwa diterapkannya metode picture to picture pada pembelajaran berbasis daring dengan penggunaan aplikasi google classroom cukup efektif untuk melengkapi implementasi dari pendekatan pembelajaran. Dalam memahami suatu materi pembelajaran harus mengetahui inti setiap materi yang dipelajari sehingga materi yang disampaikan dapat diterima oleh siswa.

Langkah pertama, membuat materi bahan ajar yang telah disesuaikan secara jelas dan dapat dipahami oleh siswa, sehingga siswa dapat belajar dengan mudah. Kemudian mengunggah materi tersebut ke dalam aplikasi google classroom. Materi tersebut tentang bacaan pembelajaran geografi dalam bentuk word ataupun pdf dan video tentang pembelajaaran geografi sebagai referensi siswa untuk belajar. Di aplikasi google classroom juga disediakan kolom komentar yang bertujuan untuk membuka ruang diskusi antara pengajar dan siswa. Sehingga siswa dapat bertanya dengan mudah tentang materi yang dianggap sulit.

Selanjutnya untuk proses pembelajaran materi persebaran flora dan fauna disesuaikan dengan metode picture to picture melalui aplikasi google classroom.

Kegiatan pembelajaran tersebut cukup efektif, karena dengan contoh gambar persebaran flora dan fauna juga berbagai macam referensi untuk belajar sudah diunggah ke aplikasi google classroom, sehingga siswa dapat belajar dengan mudah. Selain itu siswa juga merasa senang dan nyaman dengan adanya kemudahan mengakses materi pembelajaran.

Secara keseluruhan setelah diterapkannya metode picture to picture pada materi persebaran flora dan fauna, pembelajaran geografi berbasis daring yaitu dengan penggunaan aplikasi google classroom dapat meningkatkan hasil belajar siswa. Peningkatan pada siklus dapat dilihat berdasarkan nilai hasil belajar dengan Kriteria Ketuntasan Minimal (>75).

Berdasarkan data yang sudah ada diketahui bahwa siswa yang tuntas Kriteria Ketuntasan Minimal terus meningkat dari sebelum tindakan yang berjumlah 24 siswa (67\%) meningkat menjadi 28 siswa (76\%) pada siklus I dan 32 siswa (86\%) pada siklus II. Proses 
meningkatnya per siklus dilihat dari nilai hasil soal individu pada siklus I dan II . Dari hasil sebelum siklus I mengalami peningkatan, juga pada siklus II mengalami peningkatan .

Dari hasil diatas dapat disimpulkan bahwa penggunaan metode picture to picture dengan aplikasi google classroom pada materi persebaran flora dan fauna dapat meningkatkan hasil belajar geografi siswa kelas XI IPS 3 SMA N 106 Jakarta. Hasil yang telah dicapai dalam penelitian yang telah dilakukan peneliti memperkuat pendapat para ahli ataupun peneliti terdahulu,antara lain :

1. Penelitian dengan judul PENERAPAN PICTURE AND PICTURE DALAM MENINGKATKAN HASIL BELAJAR SISWA oleh ISMAN

Hasilnya adalah peningkatan peresentase hasil belajar siswa dari sebelum tindakan, siklus I sampai siklus II. Pada pra siklus jumlah siswa yang mencapai KKM adalah 60\% , meningkat $10 \%$ pada siklus I menjadi $70 \%$. Pada siklus II jumlah siswa yang mencapai KKM meningkat sebanyak 15\% menjadi $85 \%$. Dengan demikian dapat disimpulkan bahwa penggunaan metode picture and picture dapat meningkatkan hasil belajar.

2. Penelitian dengan judul PENINGKATAN HASIL BELAJAR SISWA MENGGUNAKAN PICTURE AND PICTURE PADA PEMBELAJARAN IPS KELAS IV oleh NOBERTUS ANDE PUTERA

Hasilnya adalah peningkatan nilai rata-rata hasil belajar siswa dari siklus I sampai siklus II. Pada siklus I nilai rata-rata hasil belajar siswa 85,80 meningkat sebesar 1,60 pada siklus II menjadi 87,50 . Dengan demikian dapat disimpulkan bahwa penggunaan metode picture and picture dapat meningkatkan hasil belajar.

\section{KESIMPULAN}

Pelaksanaan Penelitian Tindakan Kelas yang dilaksanakan di kelas XI IPS 3 SMA N 106 Jakarta dengan menggunkan metode picture to picture dengan google classroom ini dilaksanakan dalam 2 siklus. Sebelum siklus pertama belum bisa mencapai hasil seperti yang diharapkan, karena siswa masih belum bisa memahami materi.

Setelah ada tindakan dan refleksi pada pelaksanaan siklus I dan II maka ada perubahan yang sangat berarti ke arah yang sangat baik. Siswa sudah menunjukkan peningkatan hasil dalam belajar Geografi. Berkaitan dengan usaha peningkatan hasil belajar bagi siswa sebaiknya menerapkan metode pembelajaran picture to picture pada materi persebaran flora dan fauna dengan pertimbangan sebagai berikut :

1. Untuk mencapai kualitas proses belajar mengajar dan kualitas hasil belajar yang baik dalam pembelajaran dengan metode Picture and picture diperlukan persiapan perangkat pembelajaran yang cukup memadai seperti : RPP, Buku atau LKPD yang harus dimiliki oleh setiap siswa, dan instrumen penilaian baik untuk formatif maupun sumatif

2. Untuk menghilangkan rasa jenuh dan bosan dalam kegiatan ini guru sebaiknya memilih dan menggunakan metode belajar yang bervariasi sesuai materi yang akan diajarkan

3. Bagi pihak lain yang ingin menerapkan pembelajaran metode Picture and picture seperti yang telah dilakukan oleh peneliti sedapat mungkin terlebih dahulu dianalisis kembali untuk disesuaikan penerapannya karena tidak selalu dan semua materi cocok dan tepat bila menggunakan pembelajaran Metode Picture and picture dan juga karena dipengaruhi oleh faktor waktu, fasilitas pendukung termasuk media pembelajaran dan karakteristik siswa yang berbeda dari masing-masing

\section{DAFTAR PUSTAKA}

Ande Putera, Nobertus. 2013. Peningkatan hasil belajar siswa menggunakan Picture and picture pada pembelajaran IPS kelas IV. Skripsi.FKIP UNTAN.Pontianak

Arikunto, Suharsimi dkk. 2006. Penelitian Tindakan Kelas. Jakarta : Bumi Aksara

Hamdani. 2011. Strategi Belajar Mengajar. Bandung : CV Pustaka Setia.

Hamdayana,Jumanta. 2019. Metodologi Pengajaran. Jakarta : PT Bumi Aksara. 
Isman 2012 Penerapan Picture and picture dalam meningkatkan hasil belajar siswa. Skripsi. FKIP Uiversitas Tanjungpura (Pontianak).

Istarani, 2011. 58 Model Pembelajaran Inovatif (Referensi Guru Dalam Menentukan Model Pembelajaran). Medan : Media Persada.

Purwanto, M.Ngalim. 1986. Prinsip-prinsip dan Teknik Evaluasi Pengajaran. Bandung : CV Remaja Karya

Riyanto, Yatim. 2010. Paradigma Baru Pembelajaran. Jakarta : Kencana Prenada Media Group.

Somantri, Lili dkk. 2016. Buku Siswa Aktif dan Kreatif Belajar Geografi untuk SMA kelas XI. Bandung : Grafindo Media Pratama

Suprijono, Agus. 2009. Cooperative Learning : Teori dan Aplikasi Paikem. Yogyakarta : Pustaka Pelajar.

Widyastuti, Ana. 2021. Optimalisasi Pembelajaran Jarak Jauh (PJJ), Daring Luring, Bdr. Jakarta : PT Elex Media Komputindo Kelompok Gramedia 